\title{
Potentiostatic Deposition and Characterization of Cuprous Oxide Thin Films
}

\author{
A. El-Shaer and A. R. Abdelwahed \\ Physics Department, Faculty of Science, KafrelSheikh University, KafrelSheikh 33516, Egypt \\ Correspondence should be addressed to A. El-Shaer; elshaer@sci.kfs.edu.eg
}

Received 26 February 2013; Accepted 31 March 2013

Academic Editors: G. Alfieri, D. K. Sarker, and J. J. Suñol

Copyright (C) 2013 A. El-Shaer and A. R. Abdelwahed. This is an open access article distributed under the Creative Commons Attribution License, which permits unrestricted use, distribution, and reproduction in any medium, provided the original work is properly cited.

Electrodeposition technique was employed to deposit cuprous oxide $\mathrm{Cu}_{2} \mathrm{O}$ thin films. In this work, $\mathrm{Cu}_{2} \mathrm{O}$ thin films have been grown on fluorine doped tin oxide (FTO) transparent conducting glass as a substrate by potentiostatic deposition of cupric acetate. The effect of deposition time on the morphologies, crystalline, and optical quality of $\mathrm{Cu}_{2} \mathrm{O}$ thin films was investigated.

\section{Introduction}

Cuprous oxide is known as P-type semiconductor with a direct band gap that absorbs solar radiation up to $650 \mathrm{~nm}$ [1]. $\mathrm{Cu}_{2} \mathrm{O}$ belongs to I-VI semiconductor compounds. $\mathrm{Cu}_{2} \mathrm{O}$ has been researched as a potential material for photovoltaic applications for several reasons: source materials are abundant and nontoxic, band gap of $1.9-2.2 \mathrm{eV}$, which can be possibly adjusted by controlling the compositions [2], can be prepared with simple and cheap methods on large scale, and theoretical solar cell efficiency is approximately $20 \%$ [3-5]. All of these properties make $\mathrm{Cu}_{2} \mathrm{O}$ a suitable material for many potential applications in solar energy conversion, electrode materials, sensors, and catalysis [69]. Various methods have been employed for the synthesis of $\mathrm{Cu}_{2} \mathrm{O}$ such as thermal oxidation, thermal evaporation, sol-gel, spray pyrolysis, reactive magnetron sputtering, $\mathrm{RF}$ magnetron sputtering, and electrodeposition [10-16]. Among them electrodeposition has shown many advantages; it is a simple, economical method for preparation of large area films with good homogeneity, and it allows a good control for the growth parameters. Electrodeposition of $\mathrm{Cu}_{2} \mathrm{O}$ involves two steps: the first step is reduction of $\mathrm{Cu}^{2+}$ ions to $\mathrm{Cu}^{+}$ions (1) and the second step is precipitation of $\mathrm{Cu}^{+}$ions to $\mathrm{Cu}_{2} \mathrm{O}$ because of the solubility limitation of $\mathrm{Cu}^{+}$ions (2) [17]

$$
\begin{aligned}
& \mathrm{Cu}^{2+}+e^{-} \\
& \longleftrightarrow \mathrm{Cu}^{+} \quad E^{\circ}=0.159 \mathrm{~V}
\end{aligned}
$$

$$
\begin{aligned}
2 \mathrm{Cu}^{+}+\mathrm{H}_{2} \mathrm{O} & \\
& \longleftrightarrow \mathrm{Cu}_{2} \mathrm{O}+2 \mathrm{H}^{+} \quad \log \left[\mathrm{Cu}^{+}\right]=0.84-\mathrm{pH} \\
2 \mathrm{Cu}^{2+}+\mathrm{H}_{2} \mathrm{O}+2 e^{+} & \\
& \longleftrightarrow \mathrm{Cu}_{2} \mathrm{O}+2 \mathrm{H}^{+} \quad \text { (overall reaction) }
\end{aligned}
$$

In this study, the effect of deposition time on the morphologies, crystal and optical quality of electrodeposited thin films is investigated.

\section{Experimental Details}

Electrodeposition of $\mathrm{Cu}_{2} \mathrm{O}$ was carried out in a threeelectrode setup consisting of platinum wire counter electrode, $\mathrm{Ag} / \mathrm{AgCl}$ reference electrode, and FTO-coated glass substrate as a working electrode. Before the electrodeposition, the FTO substrates were precleaned by sonication in acetone, isopropanol, and deionized water for 10 minutes, respectively, and then dried at $105^{\circ} \mathrm{C}$ for several hours. The electrolyte used was composed of $0.02 \mathrm{M}$ cupric acetate and $0.1 \mathrm{M}$ sodium acetate with $\mathrm{pH}$ 5.8. The electrodeposition was performed at fixed potential $-0.50 \mathrm{~V}$ versus $\mathrm{Ag} / \mathrm{AgCl}$ reference electrode using Bio-Logic SP-50 potentiostat at $60^{\circ} \mathrm{C}$. A series of samples were deposited at $5,10,15$, and 30 minutes.

The morphology of the deposited films at different experimental conditions was characterized by scanning electron 


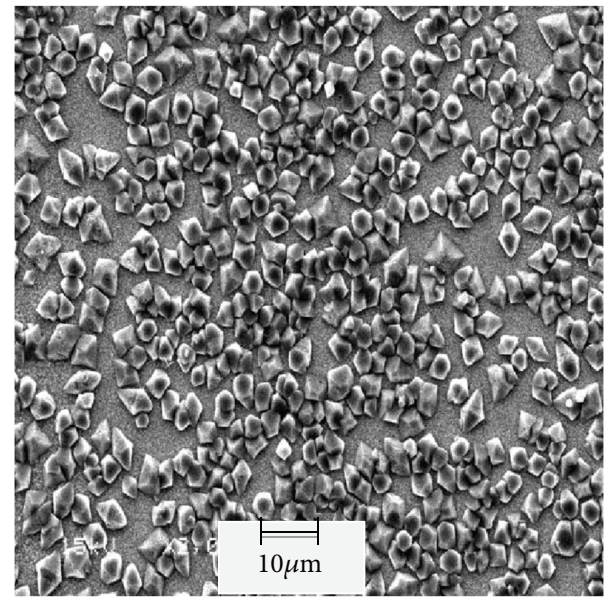

(a)

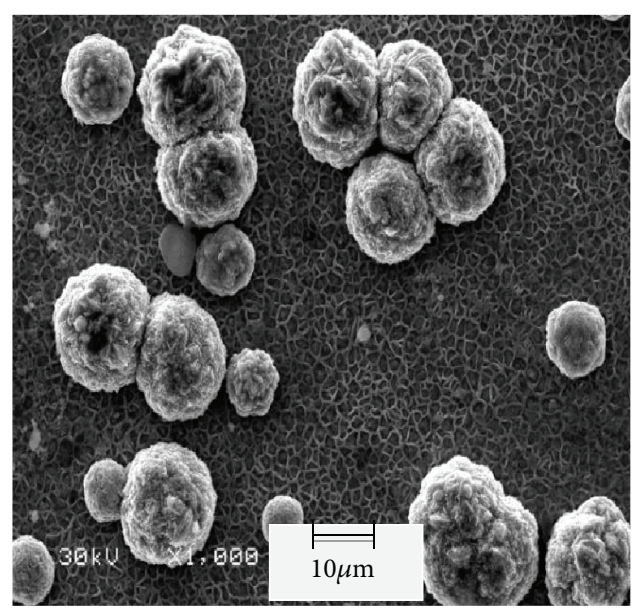

(c)

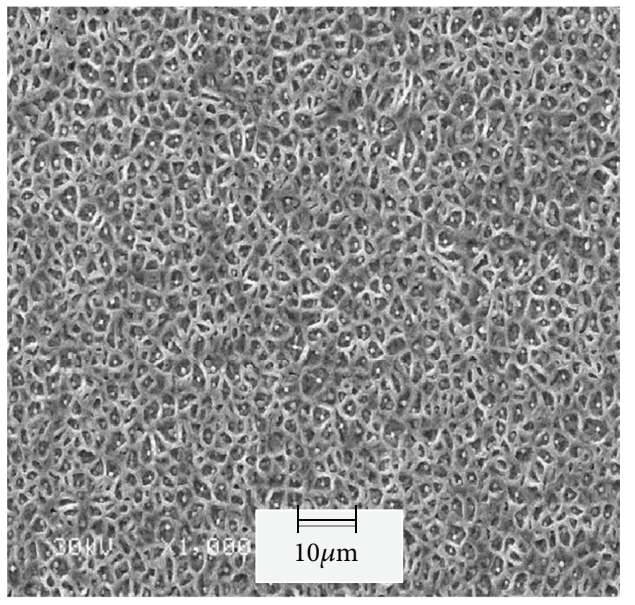

(b)

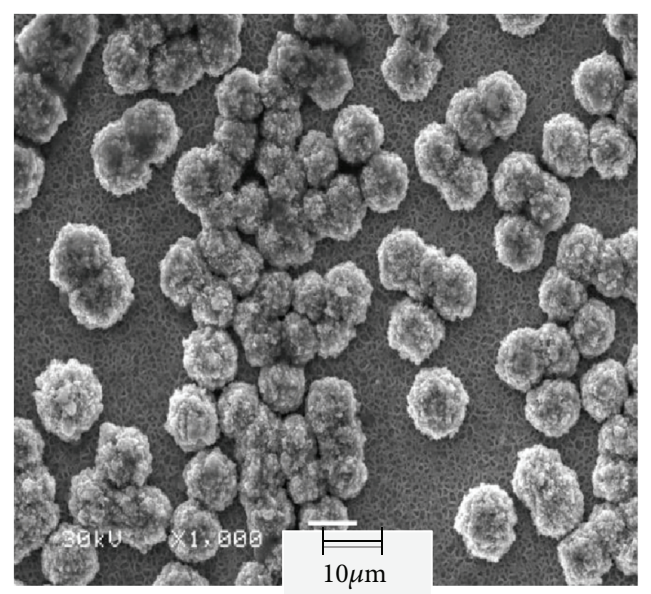

(d)

FIGURE 1: SEM photographs of $\mathrm{Cu}_{2} \mathrm{O}$ thin films deposited at various deposition times: (a) 5, (b) 10, (c) 15, and (d) $30 \mathrm{~min}$.

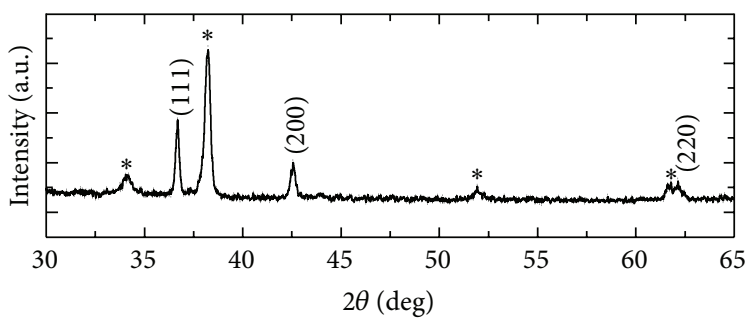

(a)

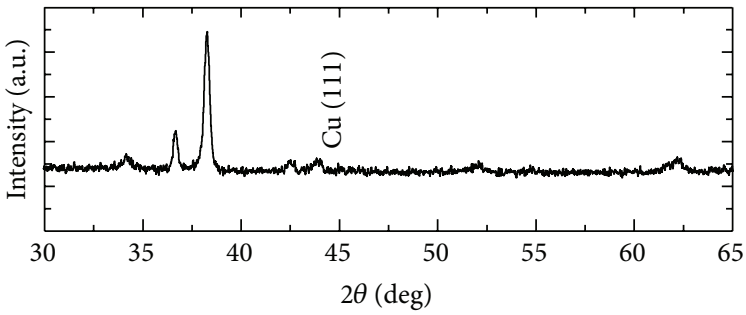

(c)

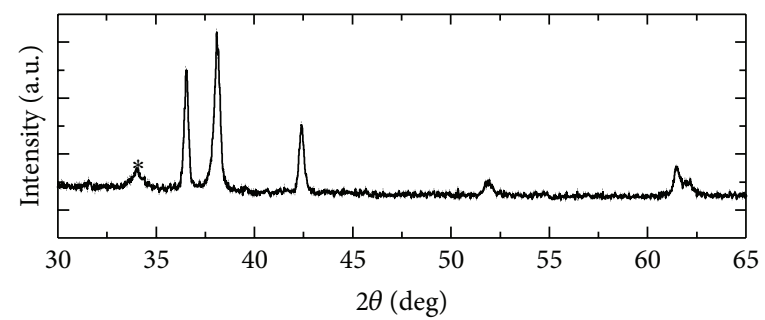

(b)

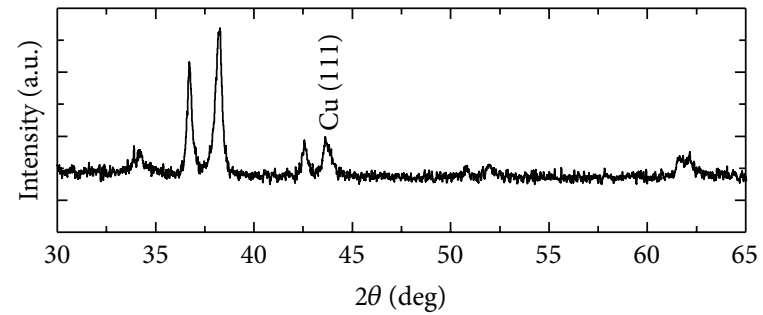

(d)

FIGURE 2: $\mathrm{XRD}$ pattern of deposited $\mathrm{Cu}_{2} \mathrm{O}$ film in electrolyte containing $0.02 \mathrm{M}$ copper acetate and $0.1 \mathrm{M}$ sodium acetate at pH 5.8 for (a) 5 , (b) 10 , (c) 15 , and (d) 30 min ( ${ }^{*}$ refers to FTO substrates). 


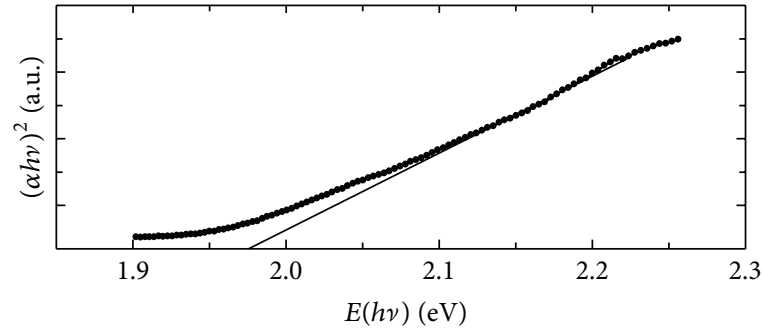

(a)

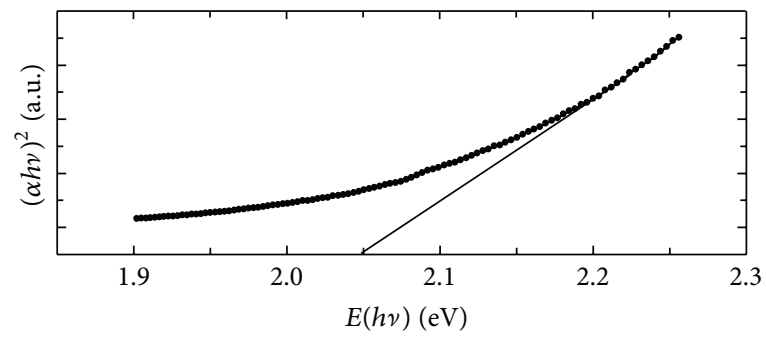

(c)

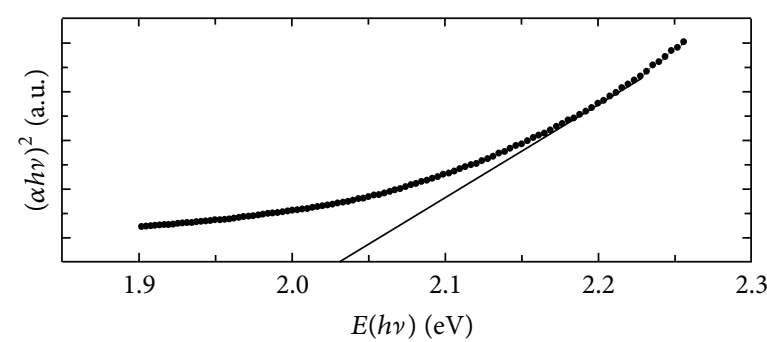

(b)

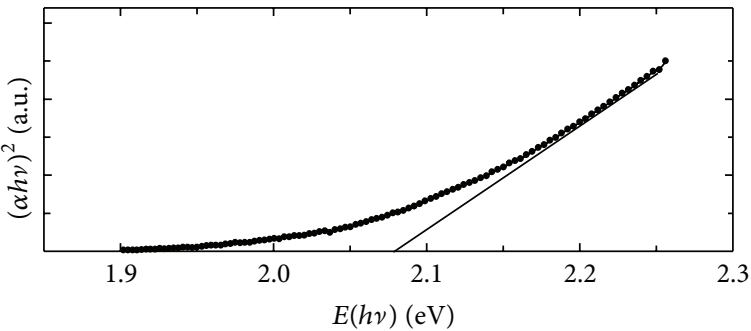

(d)

FIgURE 3: The variation of $(\alpha h \nu)^{2}$ against photon energy $E(\mathrm{eV})$ for deposited $\mathrm{Cu}_{2} \mathrm{O}$ films at different deposition times: (a) 5, (b) 10, (c) 15, and (d) $30 \mathrm{~min}$.

microscopy (SEM). Crystal structures and phase compositions of the films were measured by X-ray diffraction analysis using XRD-6000 Shimadzu diffractometer using $\mathrm{Cu}$ $\mathrm{K}_{\alpha}$ radiation $(40 \mathrm{Kv}, 30 \mathrm{~mA})$. Optical studies were carried out by recording the optical absorption spectra of the films using UV-VIS Shimadzu spectrophotometer.

\section{Results and Discussion}

Figure 1 shows SEM photographs of $\mathrm{Cu}_{2} \mathrm{O}$ thin films electrodeposited on FTO substrate at $-0.5 \mathrm{~V}$ versus $\mathrm{Ag} / \mathrm{AgCl}$ reference electrode for $5,10,15$, and 30 minutes. In the beginning of the deposition after $5 \mathrm{~min}$, a small grains starts to nucleate on the substrate surface to form cubic islands as shown in Figure 1(a). As the deposition time increased to $10 \mathrm{~min}$, the density of cube islands increased and they are interconnected with each other to change the surface morphology to be ring-shaped structures as shown in Figure 1(b) [18]. By continuing the deposition process to $15 \mathrm{~min}$, spherical grain started to appear on the surface (Figure 1(c)). Finally after 30 min deposition time, it was found that the density of the spherical grains increased to cover most of the surface as it is clear in Figure 1(d) [19].

To identify the crystal structure of the deposited films XRD measurements were carried out. These measurements indicated that all samples are crystalline and the crystallographic phase of the films is cubic as it is clear from the welldefined peaks in Figure 2. At the deposition time of $5 \mathrm{~min}$ and $10 \mathrm{~min}$, besides the characteristic peaks of the FTO glass substrate, three characteristic diffraction peaks of the $\mathrm{Cu}_{2} \mathrm{O}$ thin film at $2 \theta$ values of $36.62,42.54$, and 62.14, respectively, corresponding to the reflections from the (111), (200), and (220) planes are observed (Figures 2(a) and 2(b)). Except for the diffraction of $\mathrm{Cu}_{2} \mathrm{O}$ and FTO substrate, there are no other peaks observed, which means that pure $\mathrm{Cu}_{2} \mathrm{O}$ can be obtained through electrodeposition and no impurity phase was observed.

As the deposition time increased to $15 \mathrm{~min}$, in addition to XRD peaks of $\mathrm{Cu}_{2} \mathrm{O}$, the diffraction peak related to (111) plane of $\mathrm{Cu}$ metal appears as shown in Figure 2(c). With increasing the deposition time to $30 \mathrm{~min}$, the intensity of the $\mathrm{Cu}$ metal peak increased (Figure 2(d)). These XRD results are in good agreement with the SEM results where some spherical grains started to appear at 15 min of growth. We observed before in SEM results that some spherical grains started to appear at 15 min which is the same time when Cu metallic characteristic peak appears in XRD chart. From both SEM and XRD one can explain that these spherical grains are metallic copper. Song et al. have proved this explanation with XPS (X-ray Photoelectron Spectra) measurements [19].

The optical absorption of electrodeposited $\mathrm{Cu}_{2} \mathrm{O}$ films was recorded using a double-beam spectrophotometer in the wavelength region $200-800 \mathrm{~nm}$.

The absorption coefficient satisfies the equation $(\alpha h \nu)^{2}=$ $A\left(h \nu-E_{g}\right)$ for a direct band gap material. The band gap $\left(E_{g}\right)$ is obtained by extrapolation of the plot of $(\alpha h \nu)^{2}$ versus $E$ where $\alpha$ is the absorption coefficient as shown in Figure 3 and was found to be $1.99 \mathrm{eV}-2.16 \mathrm{eV}$ for the deposited films, which agrees well with the values reported earlier [1].

\section{Conclusion}

In this work, we report the electrochemical deposition of $\mathrm{Cu}_{2} \mathrm{O}$ thin films on FTO substrate by cathodic reduction of cupric acetate. The applied potential was $-0.5 \mathrm{~V}$ versus $\mathrm{Ag} / \mathrm{AgCl}$ reference electrode. We found that the deposition time has strong effect on the composition and crystal quality 
of the $\mathrm{Cu}_{2} \mathrm{O}$ thin films and 10 minutes is the preferable time for the deposition of high-quality $\mathrm{Cu}_{2} \mathrm{O}$ thin films. Optical absorption measurements indicate that the band gap of $\mathrm{Cu}_{2} \mathrm{O}$ thin films is $1.9-2.1 \mathrm{eV}$.

\section{Acknowledgment}

This study was supported by Egyptian Science and Technological Development Fund (STDF), call name: Renewable Energy Research Program, Project ID: 1473.

\section{References}

[1] W. Septina, S. Ikeda, M. A. Khan et al., "Potentiostatic electrodeposition of cuprous oxide thin films for photovoltaic applications," Electrochimica Acta, vol.56, no. 13, pp. 4882-4888, 2011.

[2] L. Wan, Z. Wang, Z. Yang, W. Luo, Z. Li, and Z. Zou, "Modulation of dendrite growth of cuprous oxide by electrodeposition," Journal of Crystal Growth, vol. 312, no. 21, pp. 3085-3090, 2010.

[3] L. C. Olsen, F. W. Addis, and W. Miller, "Experimental and theoretical studies of $\mathrm{Cu}_{2} \mathrm{O}$ solar cells," Solar Cells, vol. 7, no. 3, pp. 247-279, 1982.

[4] E. Fortin and D. Masson, "Photovoltaic effects in $\mathrm{Cu}_{2} \mathrm{OCu}$ solar cells grown by anodic oxidation," Solid State Electronics, vol. 25, no. 4, pp. 281-283, 1982.

[5] R. J. Iwanowski and D. Trivich, "Enhancement of the photovoltaic conversion efficiency in $\mathrm{Cu} / \mathrm{Cu}_{2} \mathrm{O}$ schottky barrier solar cells by $\mathrm{H}^{+}$ion irradiation," Physica Status Solidi A, vol. 95, no. 2, pp. 735-741, 1986.

[6] I. Rodriguez, P. Atienzar, F. Ramiro-Manzano, F. Meseguer, A. Corma, and H. Garcia, "Photonic crystals for applications in photoelectrochemical processes: photoelectrochemical solar cells with inverse opal topology," Photonics and Nanostructures, vol. 3, no. 2-3, pp. 148-154, 2005.

[7] R. W. J. Scott, S. M. Yang, G. Chabanis, N. Coombs, D. E. Williams, and G. A. Ozin, "Tin dioxide opals and inverted opals: near-ideal microstructures for gas sensors," Advanced Materials, vol. 13, no. 19, pp. 1468-1472, 2001.

[8] M. Acciarri, R. Barberini, C. Canevali et al., "Ruthenium(platinum)-doped tin dioxide inverted opals for gas sensors: synthesis, electron paramagnetic resonance, Mössbauer, and electrical investigation," Chemistry of Materials, vol. 17, no. 24, pp. 6167-6171, 2005.

[9] K. H. Yoon, W. J. Choi, and D. H. Kang, "Photoelectrochemical properties of copper oxide thin films coated on an n-Si substrate," Thin Solid Films, vol. 372, no. 1, pp. 250-256, 2000.

[10] M. J. Siegfried and K.-S. Choi, "Directing the architecture of cuprous oxide crystals during electrochemical growth," Angewandte Chemie International Edition, vol. 44, no. 21, pp. 32183223, 2005.

[11] A. L. Daltina, A. Addadb, and J. P. Choparta, "Potentiostatic deposition and characterization of cuprous oxide films and nanowires," Journal of Crystal Growth, vol. 282, p. 414, 2005.

[12] B. Balamurugan and B. R. Mehta, "Optical and structural properties of nanocrystalline copper oxide thin films prepared by activated reactive evaporation," Thin Solid Films, vol. 396, no. 1-2, pp. 90-96, 2001.

[13] L. Gou and C. J. Murphy, "Solution-phase synthesis of $\mathrm{Cu}_{2} \mathrm{O}$ nanocubes," Nano Letters, vol. 3, no. 2, pp. 231-234, 2003.
[14] Z. Wu, M. Shao, W. Zhang, and Y. Ni, "Large-scale synthesis of uniform $\mathrm{Cu}_{2} \mathrm{O}$ stellar crystals via microwave-assisted route," Journal of Crystal Growth, vol. 260, no. 3-4, pp. 490-493, 2004.

[15] Z. Z. Chen, E. W. Shi, Y. Q. Zheng, W. J. Li, B. Xiao, and J. Y. Zhuang, "Growth of hex-pod-like $\mathrm{Cu}_{2} \mathrm{O}$ whisker under hydrothermal conditions," Journal of Crystal Growth, vol. 249, no. 1-2, pp. 294-300, 2003.

[16] P. Taneja, R. Chandra, R. Banerjee, and P. Ayyub, "Structure and properties of nanocrystalline $\mathrm{Ag}$ and $\mathrm{Cu}_{2} \mathrm{O}$ synthesized by high pressure sputtering," Scripta Materialia, vol. 44, no. 8-9, pp. 1915-1918, 2001.

[17] M. Pourbaix, Atlas of Electrochemical Equilibrium in Aqueous Solutions, National Association of Corrosion Engineers, Houston, Tex, USA, 2nd edition, 1974.

[18] Y. Tang, Z. Chen, Z. Jia, L. Zhang, and J. Li, “Electrodeposition and characterization of nanocrystalline cuprous oxide thin films on $\mathrm{TiO}_{2}$ films," Materials Letters, vol. 59, no. 4, pp. 434438, 2005.

[19] Y.-J. Song, S.-B. Han, H.-H. Lee, and K.-W Park, "Sizecontrolled $\mathrm{Cu}_{2} \mathrm{O}$ nanocubes by pulse electrodeposition," The Korean Electrochemical Society, vol. 13, no. 1, pp. 40-44, 2010. 

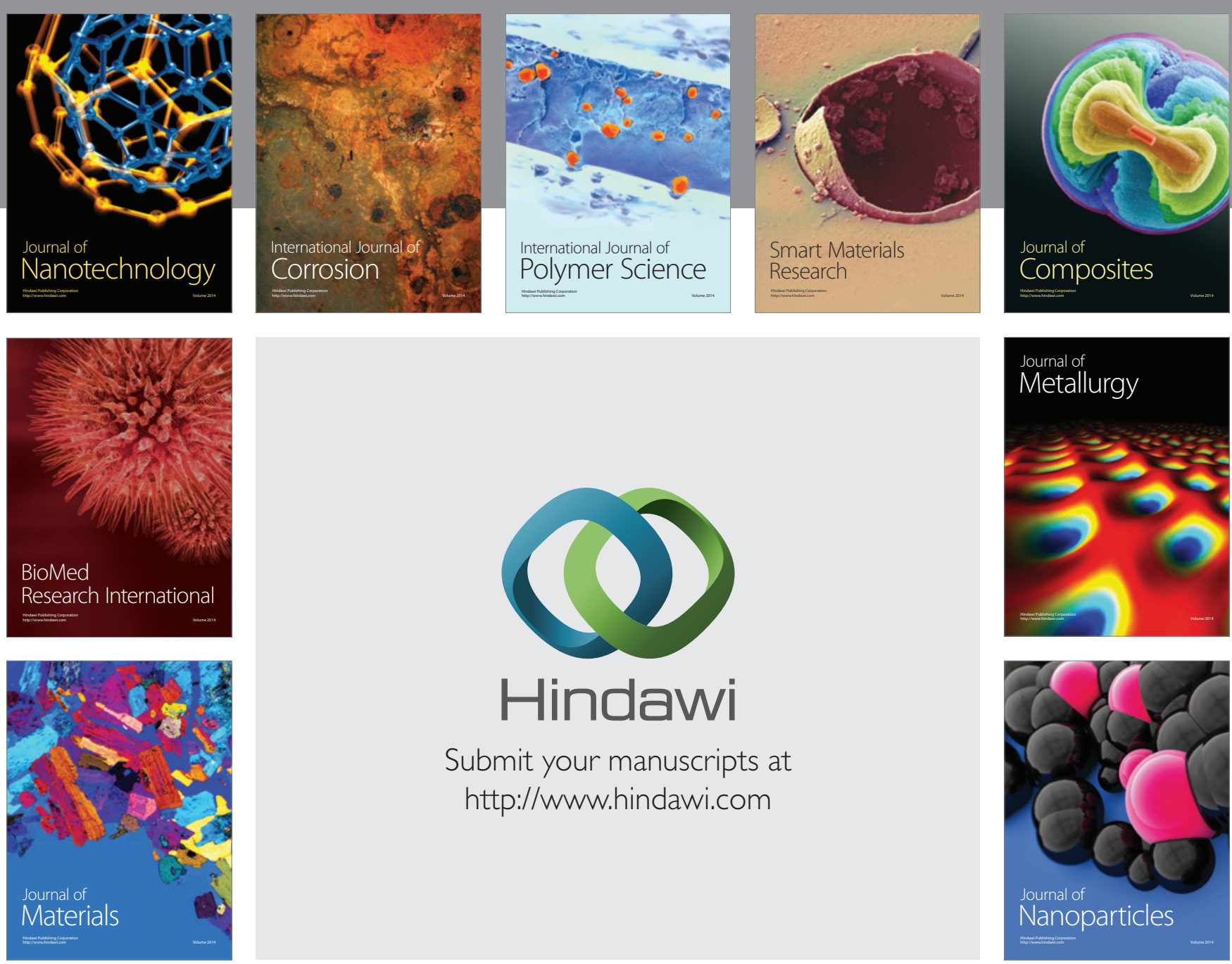

Submit your manuscripts at http://www.hindawi.com
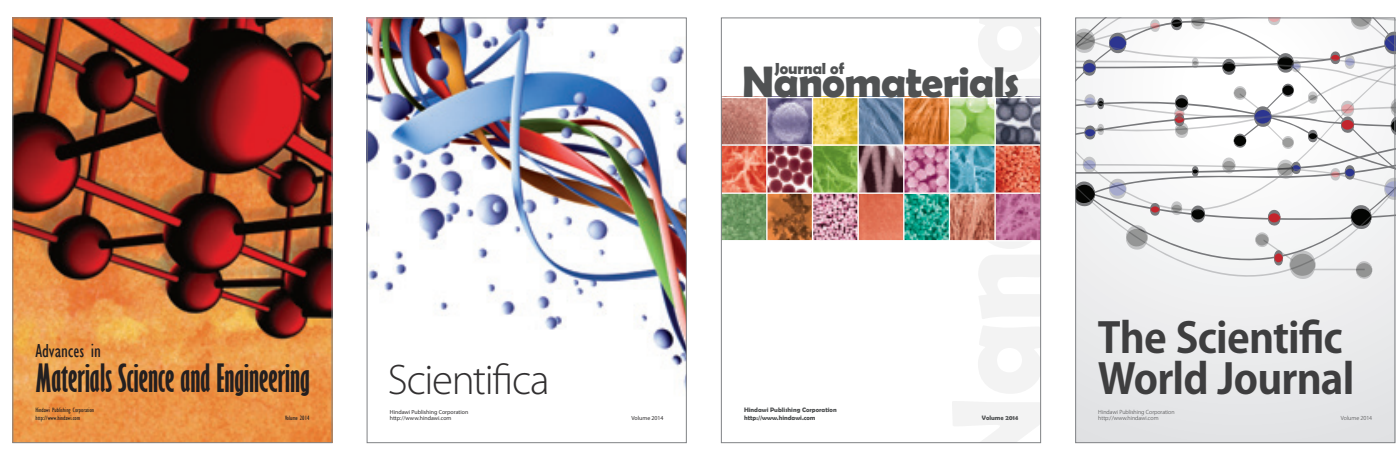

\section{The Scientific World Journal}
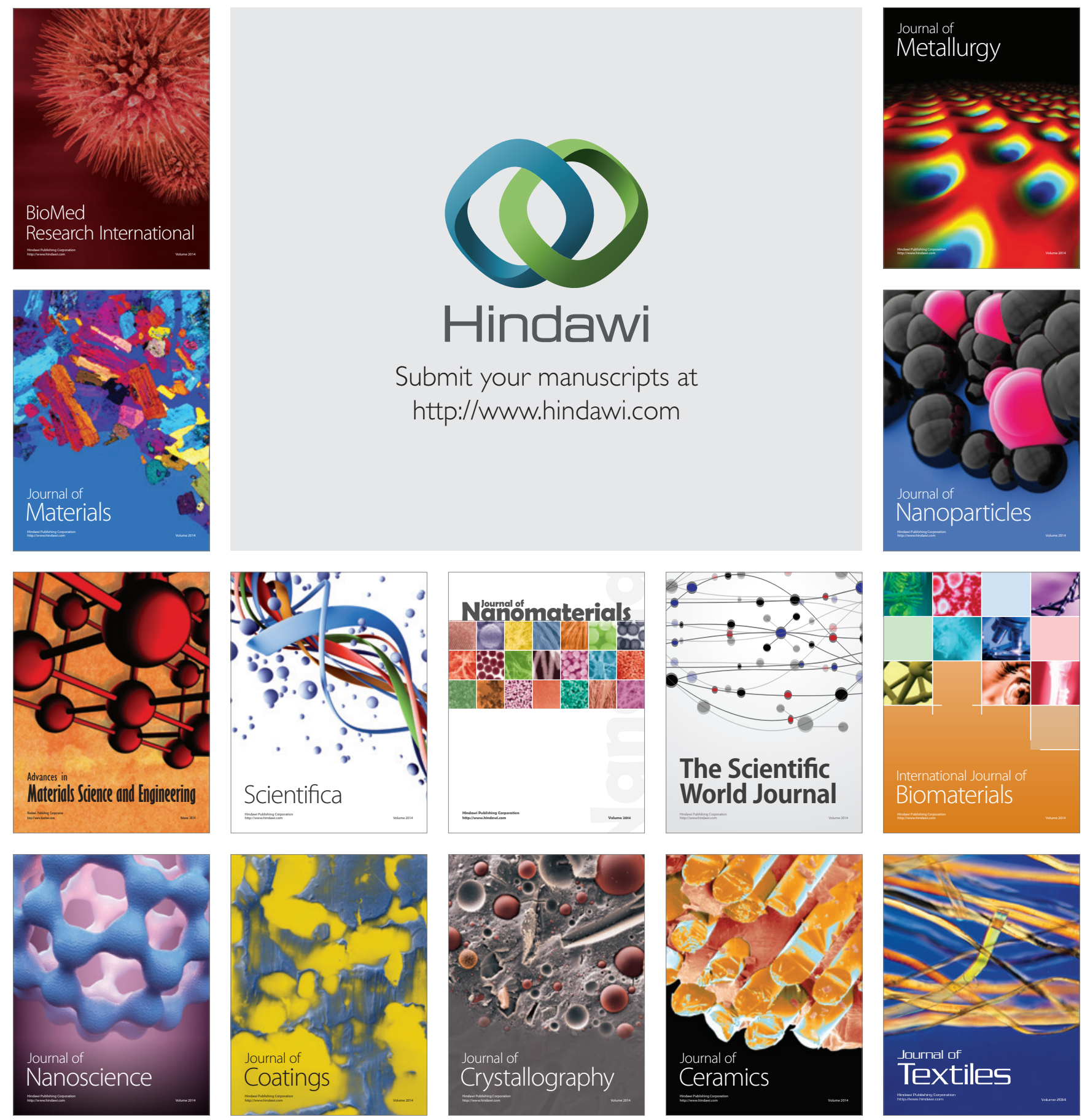